\title{
Exploration and Practice of Biochemistry Teaching for Food Specialty Based on Core Competence
}

\author{
Ling $\mathrm{Li}^{1,2}$ \\ ${ }^{1}$ College of Food Science and Biotechnology \\ Tianjin Agricultural University \\ ${ }^{2}$ Tianjin Engineering Research Center of Agricultural \\ Products Processing \\ Tianjin, China \\ liling19820925@163.com \\ Juanjuan $\mathrm{Bai}^{3}$ \\ ${ }^{3}$ College of Food Science and Biotechnology \\ Tianjin Agricultural University \\ Tianjin, China \\ 1160478383@qq.com
}

\author{
Yani Chang ${ }^{3}$ \\ ${ }^{3}$ College of Food Science and Biotechnology \\ Tianjin Agricultural University \\ Tianjin, China \\ 1716165629@qq.com
}

\begin{abstract}
The exploration was carried out in order to help students improve their core competitiveness in the face of fierce competition and a new era of talent. In the process of exploration, it mainly through adjusted teaching content, highlighted the teaching focus, improved teaching methods, built interactive teaching and strengthen the cultivation of students' practical ability as well as the overall quality of students, especially cultivated of moral qualities in these areas to comprehensively enhance the core competitiveness of students.
\end{abstract}

Keywords-core competence; interactive teaching; practice; method

\section{INTRODUCTION AND PURPOSE}

"Core competitiveness" comes from the word "enterprise core competitiveness", first proposed by us economists, CK Prahalad and Gary Hamel in 1990. The term "enterprise core competitiveness" refers to the company's main ability, which is difficult or unattainable by other companies. With the development of society, "the core competitiveness of enterprises" slowly extended to the "personal core competitiveness". This requests us in the big market of social talented person's fully demonstrate ourselves "personality", make us difficult to imitate and irreplaceable, and thus in a many talents society in a firm footing. In the development of higher education, cultivating students' "core competence" is not only for students to create competitive value, but also to improve the school "core competitiveness" ${ }^{[1]}$.

Biochemistry is a subject that studies the chemical nature of life phenomena, it covers the chemical composition, properties and functions of life substances and the changes and energy conversion of various chemicals in life. In recent years, its development is very rapid, has been involved in agriculture, industry, food science, health and other industries. For the food profession, biochemistry is a basic discipline, food processing, preservation and other processes are based on the principles of biochemistry. The importance of Food Biochemistry is self-evident. The course requires students to be proficient in applying the principles and experimental techniques learned in the classroom to the practice of food processing[2]. Improve the "core competitiveness" of students is a comprehensive. The each subject of teaching methods and teaching process can affect the students' personal qualities and personal ability. In order to make students in learning knowledge at the same time, it also learns to translate knowledge into practical ability. The work life has stronger adaptability, more personal skills such as problem solving ability. According to our many years of teaching experience, the author explores the teaching of biochemical chemistry of food specialty, mainly from the aspects of teaching content improvement, the creation of new teaching methods and the improvement of students' practical ability and moral cultivation.

\section{THE TEACHING CONTENT IS HIGHLIGHTED, ADVANCING WITH} THE TIMES

Biochemistry is a foundational discipline. It covers a wide range and difficult knowledge. So the learning process is rather dull and boring. For students, if there is no clear learning goals and plan, it is easy to more mixed and chaos in the learning. Therefore, in the course of teaching, teachers should construct the teaching plan reasonably, grasp the key and emphasize the difficult points. In view of the many characteristics of biochemical knowledge points, you can systematize after the system teaching. For example, the whole biochemistry can be divided into three parts, which is static, 
dynamic and functional biochemical ${ }^{[1]}$. It can also be divided into protein structure and function, sugar and lipid structure and function, nucleic acid structure and function, enzyme and coenzyme structure and functional, biological oxidation and metabolic and metabolic pathways in six parts. According to the characteristics of each part, the systematization of teaching content easy to grasp the teaching process, understand knowledge, can speak quickly even arranging students selfstudy after class, and also let the students know the heavy difficulty of each part clearly. In addition, the systematic teaching content should pay attention to between the module and the convergence in order to improve student learning efficiency.

With the rapid development of science and technology, knowledge is always constantly changing, the 21st century is the era of life science, and biotechnology development is changing with each passing day. In the construction of teaching content, more to avoid a dust is changeless, always pay attention to the latest published scientific research achievements, refer to the newly published materials both at home and abroad, adjust the teaching plan, train students' attention to scientific research, discover new knowledge learning habits, stimulate students interest in learning ${ }^{[2]}$. In order to improve students' ability, they can guide students to distinguish between "key points" and "difficulties" in their daily life, and organize their lives in a systematic way.

\section{IMPROVE TEACHING METHODS AND CREATE INTERACTIVE TEACHING}

In the teaching process, teaching methods directly affect the teaching results. Reasonable and efficient way of teaching not only to stimulate students interest in learning, a great extent to improve student achievement. The traditional teaching methods are generally "I hear you say", the classroom is easy to become a teacher's stage, students participate is less, classroom atmosphere cool. In such a passive learning environment, students learning enthusiasm is low, the teacher's enthusiasm is easy to be eroded. In addition, biochemistry itself is a boring discipline, so easy and lively teaching method is particularly important for it. To create a relaxed and lively teaching method, the key is that mobilize students to learn interest, so that everyone is involved in the classroom. To build interactive teaching, through interaction with students and teachers can get to know the students' learning situation in time, thus adjust the teaching progress. Students can stimulate learning enthusiasm by interacting with teachers. The author summarizes through the practice teaching, that the more efficient interactive teaching methods mainly are interchange role, classroom debate, problem induction, case law.

\section{A. Change roles}

Change roles is to exchange the role of students and teachers, so that students say and teachers listen. Take out the appropriate class time, make arrangements for each student needs to explain the chapters content, assign the task ahead of time, let the students after class to consult materials, books, also refer to related images, video, etc., prepared slides. During the lecture, the teacher only plays the role of the student, does not participate in the classroom content explain, but can ask the students questions, other students can also ask questions, after school teachers and then appropriate to supplement the classroom situation. In order to improve students' enthusiasm, a certain reward system can be set up to encourage students who are ready full. Student plays the role of the teacher, everyone has a certain pressure. It will fully arouse their learning enthusiasm. In addition, every student is performed different teaching ways. The diversity of the classroom also increases their interest in learning. In change roles part, students' individual ability, especially resolved problem, was promoted. Students need not only their own data access, ensure lectures in the face of classroom questioning, can rise the occasion, and solve problems by themselves.

\section{B. Classroom debate}

In addition to the daily teaching, there are some controversial issues in class, which can be arranged to organize students to debate. Students are free to assign pros and cons, check data collection arguments, free speech during debates, and fully stimulate thinking activity. So that they can distinguish right from wrong and seek truth in argument. The safety of genetically modified foods has always been a more controversial issue in China's food safety issue. It can be used as a subject of debate, as a point of view of students' self to elaborate their own views, to learn both knowledge and thinking in the course of the debate.

\section{Problem induction}

In class, although students face the same shared resources, but based on the individual's quality is different, so students can not be treated the same training. Fully understand students of the course content is not much. There are more or less understanding of the blind area for most students. In the face of students doubts, students can know the answer, not only for a question to explain, but there is no deep thinking, or in the follow-up study is easy to appear similar confusion again. In order to help students to "cure" problem, solve doubts, teachers can in the teaching process with the appropriate class, statistics collection problems arising from the students in the learning process. In addition to the interpretation of the problem, it is likely to be students grasp of the corresponding knowledge for some high frequency problems, should find its related knowledge, and to do further more detailed explanation. In the process of answer, we guide students to learn to sum up, classify the problems, open their own knowledge structure, find out weak spot, targeted to strengthen learning, avoid entering wrong step.

\section{Case law}

Case law is also an organized activity, easier to stimulate students to participate in the enthusiasm. Case analysis is to transform the problems that occur in the practice into cases, so that students can think deeply and analyze the problems, and put forward some solutions or evaluation according to the theoretical knowledge. It is a comprehensive process, not only cultivate the students rigorous way of thinking, but also allow them to lean to use. The textbook knowledge into practical ability to solve the problem, but also to stimulate their active learning passion, in the implementation of case law, teachers can use multimedia tools to help students to carry out ${ }^{[3]}$. 


\section{PAY ATTENTION TO PRACTICAL TEACHING AND IMPROVE STUDENTS' PRACTICAL ABILITY}

Poet saadi said "a man of knowledge practice, not equal to a bee honey". Practice is the sole criterion for testing truth in the process of modern teaching, practice teaching gradually become an indispensable part of teaching process, and practical ability is also a important standard of social talents. Although the practice teaching has been trying to infiltrate education, the effect is not satisfactory. Students prone to slack off in the practice according to the traditional thinking and theoretical achievement. The teachers also lack of corresponding practical teaching experience in the long term. The students are "theory", and the beginning ability is low, lack innovation in the face of fierce competition of selecting talents market, easy to be eliminated. For practice, we don't need to be superficial, should not be confined to the experimental class, to really do a good job of practical teaching, breaking the shackles of traditional thinking, training students practical ability and practical consciousness.

The first step of practice teaching, should let students themselves attaches great importance to education practice. Because our country's higher education, the practice part not in the final examination as the object in theory achievement, students ignor the practice. In order to improve this bad situation, you can add the practice assessment project in the final assessment. If the assessment can not pass the results and theoretical results fail the same, correspondingly if the academic performance is excellent, the same reward is given students. So that students can attach their own practical ability, learning spontaneous. In addition, students now are facing after graduation to integrate difficult problem. For example, a very good student in school, are likely to feel the bigger gap when step into society. This is the problem because of low social practice ability. To avoid derailment of students and society, it cannot be ignored in daily teaching to cultivate students' social practice ability, especially for graduated students. Therefore, it can be for junior and senior students in school and company joint training projects. Schools for different professions to find the appropriate conditions for the company, arrange a certain class for students to study in the company, we can follow the wishes of students choose their own departments. Of course, the company will set up a special assessment system, urging them to seriously complete the practical work. With the emphasis on practice, practice teaching methods are more and more diversified, choose the appropriate teaching methods, will do a thorough job, do not stay on the surface, really cultivate the practical ability of students ${ }^{[4]}$.

\section{STRENGTHEN THE RELATIONSHIP BETWEEN TEACHERS AND STUDENTS AND PAY ATTENTION TO THE MORAL CULTIVATION} OF STUDENTS

Teacher is the learning of knowledge navigator, solve problems for students, is crucial for student achievement. At the same time, the teacher for students and the role of elders, affect students' way of thinking and values, etc.. So teachers in the teaching process should be strict with themselves, in addition to constantly enrich update knowledge reserve, optimizing teaching methods, to strengthen the construction of good relationship between teachers and students. To be more concerned with students in life, to know students, not to judge students by the grades of students, to be good at discovering the potential characteristics of students, to encourage students to enrich themselves. Good relationship between teachers and students is also the premise of improve student achievement. The classroom appeal will naturally increase with "relationship". It will stimulate student to study the passion, but also can improve the rigidity of classroom atmosphere, let the student bold in learning, to don't understand the problem in a timely manner, no longer timid retreat ${ }^{[5]}$.

Teachers in imparting knowledge, the same should also pay attention to the cultivation of students' moral quality, follow the principle of doing things after the first person, do not blindly focus on student achievement, while ignoring moral achievements, cultivate "high quality" criminals. Especially for the food industry, the temptation is greater and more, illegal consequences are more serious. In recent years, frequent exposure to food safety issues, has gradually reducing people's trust in China's food safety, even so, driven by the interests, All kinds of illegal production, illegal business is still continuing. Food professional students, most graduates will join the food industry, have to face the greater temptation. As educators, teaching and educating is our duty, we must strictly the students' moral bottom line, cultivate students to form a solid and correct social outlook, values, maintain social peace. Compared to excellent academic performance, this is the most important heavy, but also to cultivate students awareness of right and wrong. For the wrong doing, it not only do not participate, but also do not cover, do not condone, timely expose, punish evil.

\section{CONCLUSIONS}

Along with the rapid development of science, technology and social economy, social competition is also increasing. This is an era of lifelong learning, focus on the development of a more human resources and the value of time, so we should strengthen the cultivation of the core competence of students, let them back on its feet in this era. we adjust teaching content, build interactive teaching, strengthen the practice of education and moral training in the teaching work. To a certain extent, it will improve the quality of students, increase the core competitiveness of students. In the future, teaching work also needs to continue explore forward, keep up with the pace of social development, training students core competitiveness, provide talent for the community.

\section{ACKNOWLEDGMENT}

This work was supported by grants from the Tianjin Agricultural University Education Teaching Reform Research Project (No. 2016-B-07) and the Tianjin Agricultural University Teacher Education Reform and Innovation Guide Development Project (No. 20170412).

\section{REFERENCES}

[1] Q.L. Wang, and J.L. Chen, Teaching reform and practice of food science and technology based on core competencies for cultivating. Xinjiang Shihezi University, Food College, vol. 17, pp. 137, 2012. (In Chinese) 
[2] X.Z. Kong, The exploration and practice of food specialty biochemistry course teaching. Education Teaching Forum, vol. 14, pp. 143-144, 2015. (In Chinese)

[3] J.K. Yan, Exploration on innovative teaching of biochemistry in food specialty at colleges. Academic Periodical of Farm Products Processing, vol. 12, pp. 137-139, 2011. (In Chinese)
[4] D. Peng, and J.W. Xiong, Preliminary study on interactive teaching mode of food biochemistry in classroom. Teaching and Practice, pp. 4243, 2012. (In Chinese)

[5] L. Feng, H.L. Zhang, J. Yan, F. Shi, L.C. Ren, and F.L. Chen, Teaching problem and countermeasure of food biochemistry, Anhui Agricultural Science Bulletin, vol. 20, pp. 154-156, 2014. (In Chinese) 